\title{
Analisis Kebutuhan Anak Usia Dasar dalam Pembelajaran Berbasis Daring pada Masa Pandemi Covid-19
}

\author{
Imam Hanafi \\ Universitas Wiraraja Madura, Indonesia \\ imamhanafi@wiraraja.ac.id
}

\begin{abstract}
Abstrak
Artikel ini bertujuan untuk menganalisis kebutuhan anak usia dasar dalam pembelajaran berbasis daring pada masa pandemi covid-19. Penelitian yang mencoba menganalisis kebutuhan anak usia dasar dalam rangka keberlangsungan, kenyamanan, dan kesejahteraan hidup. Dimana kebutuhan anak usia dasar dalam sistem pembelajaran sangat berbeda dengan kebutuhan orang-orang dewasa, terutama pada saat pembelajaran yang dilaksanakan secara daring. Metode penelitian menggunakan metode kualitatif jenis telaah pustaka. Hasil analisis menunjukkan bahwa kebutuhan anak usia dasar mencakup enam aspek yakni kebutuhan fisiologis, kebutuhan akan rasa aman, kebutuhan kasih asayang dan perhatian, kebutuhan terhadap reward atas prestasi yang dicapai, kebutuhan akan sarana untuk aktualisasi diri, serta kebutuhan akan rasa sukses. Oleh karenanya, pembelajaran di tengah pandemi covid-19 berbasis daring harus memperhatikan pemenuhan kebutuhan anak dari segi kemampuan berfikir dan bergerak yang masih sangat terbatas. Hal tersebut menjadi kewajiban pihak eksternal. Maka orang tua dan guru harus memahami tingkat kebutuhan serta karakter anak agar mencapai tujuan pembelajaran, yakni terbentuknya pribadi yang beriman, cerdas dan berkarakter meski ditengah pandemi.
\end{abstract}

Kata Kunci: anak, pembelajaran, kebutuhan, daring 


\begin{abstract}
This article aims to analyze the needs of basic age children in onlinebased learning during the Covid-19 pandemic. Research that tries to analyze the needs of basic age children in the context of survival, comfort, and well-being of life. Where the needs of basic age children in the learning system are very different from the needs of adults, especially when learning is carried out online. The research method uses a qualitative method of literature review. The results of the analysis show that the needs of basic age children include six aspects, namely physiological needs, the need for security, the need for love and attention, the need for rewards for achievements, the need for means for self-actualization, and the need for a sense of success. Therefore, online-based learning in the midst of the Covid-19 pandemic must pay attention to meeting the needs of children in terms of the ability to think and move, which is still very limited. This is the obligation of external parties. So parents and teachers must understand the level of needs and character of children in order to achieve learning goals, namely the formation of a person who is faithful, intelligent and has character even in the midst of a pandemic.
\end{abstract}

Keywords: children, learning, needs, online

\title{
PENDAHULUAN
}

Dalam penciptaannya, Allah menciptakan manusia sebagai makhluk yang sempuna dibandingkan dengan makhluk lainnya. Tidak hanya kesempurnaan fisik, Allah memberi akal kepada manusia yang menjadi pembeda dengan makhluk ciptaan Allah lainnya untuk menjalani kehidupan di dunia. Pada dasarnya manusia juga diciptakan sebagai makhluk sosial yang hidup berdampingan dan saling membantu satu lainnya. Oleh karena itu, manusia memiliki kebutuhan-kebutuhan wajib dan mendasar yang harus terpenuhi dan tidak bisa dihindari. Kebutuhuan tersebut meliputi kebutuhan fisiologis dan kebutuhan non-fisiologis.

Gagasan mengenai kebutuhan manusia ini digagas oleh Maslow. Dimana kebutuhan manusia pada hakikatnya bersifat hierarki dan berjenjang, artinya setiap jenjang kebutuhan akan 
terpenuhi jika jenjang sebelumnya terpuaskan secara relatif dimulai dari tingkatan yang lebih rendah menuju kebutuhan yang tingkatannya lebih tinggi. ${ }^{1}$

Di setiap tahap proses perkembangannya, manusia memiliki kebutuhan yang berbeda dalam tingkatannya. Baik dari segi tahap anak-anak usia dasar, usia remaja, usia dewasa dan usia tua. Adapun perbedaan kebutuhan tersebut biasanya terlihat dari jenis, ukuran atau levelnya. Pada anak usia dasar, kebutuhan-kebutuhan yang harus dipenuhi sangat bergantung terhadap orang lain (orang tua, kakak, guru, teman dan lain sebagainya). Hal ini disebabkan karena mereka belum mampu memenuhi kebutuhannya secara personal. Misalnya, untuk memenuhi kebutuhan fisiologis, kecil kemungkinan anak-anak harus bekerja. Karena mereka masih memiliki keterbatasan dalam berfikir, bergerak, dan bekerja layaknya seperti orang dewasa.

Demikian pula kebutuhan anak usia dasar dalam hal pembelajaran, guru dan orangtua dituntut harus mengetahui tahapan perkembangan anak sesuai kebutuhan-kebutuhannya. Hal ini bertujuan agar pembelajaran dapat tercapai teruma di saat Indonesia dilanda pandemi Covid-19. Dimana dampaknya merubah hampir seluruh tatanan kehidupan masyarakat, salah satunya perubahan yang terjadi dalam dunia pendidikan. Bahkan jika dilihat hampir dua tahun pendidikan tidak memiliki aktivas di sekolah sehingga mengharuskan dilakukannya pembelajaran berbasis teknologi.

Secara umum, setiap orang tua, guru dan masyarakat harus mengambil peranan aktif dalam pemenuhan kebutuhan anak khususnya anak usia dasar berkaitan dengan pendidikannnya. Hal ini dikarenakan kesalahan dalam hal cara mendidik dapat berakibat fatal

\footnotetext{
${ }^{1}$ Alwisol, Psikologi Kepribadian (Malang: UMM Press, 2009).
} 
terhadap fisik dan psikis anak. Berdasarkan latar belakang tersebut, peneliti tertarik untuk melakukan kajian dan analisa baik secara teoritis dan empiris terhadap kebutuhan anak usia dasar dalam pembelajaran yang dilakukan secara daring.

\section{Teori Kebutuhan Dasar Manusia}

Pada hakikatnya manusia memiliki kebutuhan-kebutuhan yang wajib dan mendasar untuk dipenuhi dalam rangka keberlangsungan hidup yang nyaman, senang dan sejahtera. Menurut Afrooz, kebutuhan (need) ialah A Natural requirement which should be satisfied in order to secure a better organic compability. ${ }^{2}$ Artinya, kebutuhan merupakan suatu syarat alamiah yang harus terpenuhi untuk menjamin kebaikan, kesenangan dan kesejahteraan seseorang sesuai dengan keinginan dirinya. Di sisi lain, Chaplin mendefinisikan kebutuhan sebagai satu substansi seluler yang harus dimiliki oleh organisme agar tetap sehat. Kebutuhan tersebut bisa muncul dari individu itu sendiri maupun dari lingkungan sekitarnya.

Semua manusia dilahirkan dengan kebutuhan-kebutuhan instinktif, yaitu suatu kebutuhan-kebutuhan universal yang mendorong manusia tumbuh dan berkembang, untuk mengaktualisasikan dirinya dan untuk menjadikan semuanya sejauh kemampuan dasar yang dimiliki. Selain itu, Maslow juga mengemukakan bahwa "manusia dimotivasi oleh sejumlah kebutuhan dasar yang bersifat sama untuk seluruh spesies, tidak berubah, dan berasal dari sumber genetis atau naluriah". 3

\footnotetext{
2 Desmita, Psikologi Perkembangan Peserta Didik (Bandung: Remaja Rosda Karya, 2017), 59.

${ }^{3}$ B Mif, Psikologi Pertumbuhan (Bandung: Rosdakarya, 2008).
} 
Kebutuhan-kebutuhan yang mendominasi pribadi seseorang tidak selalu berkaitan dengan kebutuhan fisiologis (fisik), melainkan juga berkaitan dengan kebutuhan psikologis (kejiwaan). Dapat dipahami bahwa kebutuhan-kebutuhan tersebut merupakan aspek yang mesti terpenuhi dalam keberlangsungan hidup manusia itu sendiri. Disisi lain, manusia juga memiliki kelemahan yang sewaktuwaktu dapat dengan mudah terkendali dan terpengaruh oleh lingkungannya. Pada hakikatnya, walau sewaktu-waktu kebutuhan tersebut telah terpenuhi, namun kebutuhan masih tetap tidak terpuaskan bahkan akan melahirkan tuntutan-tuntutan dari kebutuhan yang lainnya. Hal ini akan terus terjadi dalam diri setiap individu setiap saat, jika hawa nafsu mendominasi pribadi individu tersebut.

Berdasarkan penjelasan-penjelasan di atas, dapat disimpulkan bahwa pada hakikatnya seluruh makhluk hidup khususnya manusia pasti memiliki kebutuhan, baik yang bersifat wajib dan mendasar seperti oksigen, makan, minum dan lain-lain, maupun yang bersifat pendukung dalam perkembangan atau pertumbuhan seperti kreatif, mental, realisasi diri, dan lain-lain. Dimana kebutuhan wajib atau kebutuhan dasar sudah menjadi kebutuhan pokok yang alamiah sejak manusia berada dalam kandungan hingga terlahir di dunia. Sehingga, jelas bahwa kebutuhan tersebut dapat dikatakan sebagai sarat wajib bagi manusia untuk hidup dan bertahan hidup. Salah satu contohnya ialah ketika seseorang merasa haus dan lapar maka yang dipikirkannya bagaimana cara untuk mendapatkan makanan dan minuman secepat mungkin daripada memikirkan kebutuhan yang lain. 


\section{METODE PENELITIAN}

Berdasarkan model dan kesenjangan sebagaimana yang telah diuraikan sebelumnya, maka penelitian ini memakai pendekatan perkembangan. Pendekatan perkembangan dengan teori kebutuhan anak usia dasar yang digunakan untuk mengungkapkan bagaimana seharusnya orangtua dan guru memenuhi kebutuhan anak usia dasar dalam pembelajaran daring.

Maka dari itu, penelitian ini menggunakan metode dan pendekatan kualitatif. Penelitian kualitatif adalah prosedur penelitian yang menghasilkan data deskriptif berupa kata-kata dan simbolsimbol bahasa tertulis dan lisan dari orang-orang dan perilaku yang dapat diamati. Sebagaimana pendapat Bogdan dan Biklen:

"We use qualitaive research as an umbrella term to refer to several researcch strategis that share certain characteristic. The data collected has been termed soft, that is, rich in description of people, place, and conversation, and not easily handled by statistical procedures. "... in education, qualitative research is frequently called "naturalistic" because the researcher hangs around where the events he or she is interested in naturally occur. And the data is gathered by people engaging in natural behavior: talking, visiting, looking, eating and so on."

Berdasarkan objek kajiannya, penelitian ini termasuk penelitian studi pustaka (library research). Library Research adalah suatu penelitian yang dilakukan dengan cara mengumpulkan data, informasi dan bermacam data lainnya yang terdapat dalam kepustakaan. Sumber data yang digunakan dalam penelitian ini bersumber pada buku dan karya ilmiah terkait dengan teori kebutuhan anak usia dasar.

\footnotetext{
${ }^{4}$ Bogdan Robert C dan Biklen Sari K, Qualitative Research for Edducation: an introduction to Theory and Methods (Boston: Ailyn and Bacon, 1982), 2.
} 


\section{HASIL DAN PEMBAHASAN}

\section{Analisis Kebutuhan Anak Usia Dasar dalam Pembelajaran Berbasis Daring pada Masa Pandemi Covid-19}

Pembahasan mengenai kebutuhan dasar pada anak usia dasar tentu tidak terlepas dari pada perkembangan psikologi anak. Anak usia dasar yang memiliki bentang usia mulai dari 6-12 tahun. Menurut Erik Erikson, "dalam teori perkembangan, usia 6-10 tahun berada dalam masa pertengahan dan akhir kanak-kanak dan usia 1012 tahun berada dalam masa remaja".

Kebutuhan-kebutuhan yang harus dimiliki oleh anak tentu menyesuaikan pada taraf perkembangnnya yang meliputi perkembangan fisik, kepribadian, kognitif dan sosial-emosional. Kebutuhan-kebutuhan anak usia dasar yang mesti terpenuhi tentu lebih banyak memerlukan bantuan dari orang lain (orang tua, kakak, adik, nenek, kakek, guru, teman dan lainnya) daripada hasil usaha secara personal. Mengingat pada usia dasar, anak memiliki kekuatan dan kemampuan yang masih terbatas.

Oleh sebab itu, orang tua dan guru sebagai pihak eksternal dan orang yang lebih dewasa perlu mengetahui dan memahami jenis dan tingkat kebutuhan peserta didik anak usia dasar termasuk kebutuhan rasa ingin tahu atau kebutuhan belajar. Dapat dipahami bahwa dari segi prinsipnya, ia merupakan manifestasi pemenuhan kebutuhan kebutuhan anak. Tujuannya, agar dapat dengan mudah membantu anak dalam memenuhi kebutuhan dasarnya sesuai dengan taraf perkembangannya, baik di lingkungan keluarga, di sekolah (kegiatan belajar mengajar) dan di lingkungan masyarakat. 
Terkait dengan teori kebutuhan dasar, Maslow membangun suatu teori yang dikenal dengan hierarki kebutuhan "hierarchy of need". Teori hierarki kebutuhan dasar, terdapat lima tingkatan, yaitu: 1) kebutuhan fisiologis, 2) kebutuhan akan rasa aman dan perlindungan, 3) kebutuhan akan rasa kasih sayang dan memiliki, 4) kebutuhan akan penghargaan (harga diri) dan 5) kebutuhan akan aktualisasi diri. Berdasarkan hasil analisis tersebut, berikut ini dideskripsikan kebutuhan-kebutuhan anak usia dasar dan dalam pembelajaran berbasis daring pada masa pandemi Covid-19.

Pertama, kebutuhan-kebutuhan fisiologis (Pysiological Needs). Kebutuhan fisiologis termasuk kebutuhan yang paling dasar dan paling kuat diantara beberapa kebutuhan lainnya. Hal ini dikarenakan kebutuhan fisiologis berpengaruh pada keberlangsungan hidup secara fisik. Maka dapat disimpulkan bahwa kebutuhan fisiologis adalah sejumlah kebutuhan yang paling mendesak dan menjadi prioritas utama dalam pemenuhannya, karena berkaitan dengan kelangsungan hidup dan kondisi fisik anak.

Dalam Islam, manusia dalam konsep al-Basyr, yaitu sebagai mahluk yang memiliki unsur biologis yang membutuhkan makanan dan minuman dapat bertahan hidup. ${ }^{5}$ Kebutuhan fisiologis tersebut meliputi oksigen untuk bernafas, makanan, minuman, sandang, tempat tinggal, seks, tidur, buang air besar atau air kecil, menghindari bahaya dan penyakit, istirahat dan lain-lain. Manusia yang lapar akan selalu termotivasi untuk makan dan tidak melakukan hal lain,

\footnotetext{
5 Mualimin Mualimin, "Konsep Fitrah Manusia Dan Implikasinya Dalam Pendidikan Islam," Al-Tadzkiyyah: Jurnal Pendidikan Islam 8, no. 2 (17 November 2017): 249-66, https://doi.org/10.24042/atjpi.v8i2.2130.
} 
meskipun ia merasakan kebutuhan kasih sayang, rasa nyaman dan kebutuhan lainnya secara nyata.

Manusia akan mengabaikan semua kebutuhan lain sampai kebutuhan fisiologisnya terpenuhi dan terpuaskan. Maka, jelas bahwa kebutuhan dasar fisiologis ini merupakan kebutuhan terkuat dari semua kebutuhan. Pada kondisi normal, kebutuhan anak usia dasar terhadap makanan dan minuman tidak sebanyak kebutuhan orang dewasa.

Seharusnya kebutuhan fisiologis anak usia dasar tidak hanya makanan dan minuman saja, melainkan kebutuhan sandang juga seperti baju, celana, perlatan mandi dan peralatan sekolah. Dalam subuah teori kebutuhan dasar psikologis, Kebutuhan fisiologis erat kaitan dengan pendidikan seseorang. Niemic \& Riyan menjelaskan bahwa pemenuhan kepuasan kebutuhan dasar psikologis berkaitan dengan aktif atau pasifnya individu dalam belajar. ${ }^{6}$ Teori ini mengemukakan bahwa seseorang dapat mengikuti proses pendidikan (kegiatan belajar-mengajar) dengan baik, jika kebutuhan fisiologis telah terpenuhi.

Artinya, selama pembelajaran daring pada masa pandemi, guru harus memiliki strategi pembelajaran yang efektif agar peserta didik usia dasar tetap aktif dalam belajar. Selain itu, orangtua harus menyediakan fasilitas atau wahana untuk anak bermain dan berolahraga di rumah sebagaimana yang tersedia di sekolah.

Kedua, kebutuhan akan rasa aman dan perlindungan. Kebutuhan akan rasa aman dan perlindungan juga termasuk dalam

\footnotetext{
${ }^{6}$ St Nurjannah Yunus Tekeng dan Asmadi Alsa, "Peranan Kepuasan Kebutuhan Dasar Psikologis dan Orientasi Tujuan Mastery Approach terhadap Belajar Berdasar Regulasi Diri,” Jurnal Psikologi 43, no. 2 (1 Juni 2016): 85-106.
} 
kebutuhan dasar yang berada pada level kedua setelah fisiologis. Kebutuhan ini cenderung mendorong manusia untuk memperoleh kenyamanan, ketentraman hidup dan terjaga dari lingkungannya. Salah satunya ialah mendapat jaminan keamanan dan perlindungan dari segala ancaman dan bahaya seperti kriminalitas, perang, terorisme, penyakit, takut, cemas, bahaya, kerusuhan dan bencana.

Seseorang yang tidak mendapatkan rasa aman dan perlindungan tentu akan selalu merasa resah, gelisah, takut dan bahkan dapat berakibat lebih fatal seperti stres dan gila. Pada usia dasar, anak akan merasa aman yang cukup apabila berada dalam ikatan keluarga yang kuat dan harmoni. Sebaliknya, apabila ikatan keluarga lemah, maka anak akan merasa cemas, gelisah, tidak tentram, setres, dan kurang percaya diri. ${ }^{7}$

Kebutuhan rasa aman anak usia dasar dalam proses pembelajaran selama masa pandemi Covid-19, dapat dipenuhi dengan cara memberikan perhatian yang penuh dan menciptakan lingkungan keluarga seperti lingkungan sekolah, yakni jauh dari konflik (perkelahian dan peperangan). Selanjutnya, membatasi ruang bermain anak dari tempat-tempat yang membahayakan fisik anak. Jika kebutuhan rasa aman tidak terpenuhi, tentu akan berdampak bahaya terhadap psikologi anak (mental dan sikap). Salah satu contohnya ialah anak yang berada di wilayah konflik sosial tentu akan mengalami stres, rasa takut yang berlebihan serta trauma yang sangat mendalam dapat menjadi faktor penghambat masa depan anak.

Pemberian rasa aman ini sangat urgen agar keberhasilan belajar dapat tercapai. Jika sebelumnya sekolah yang memberikan

\footnotetext{
${ }^{7}$ A Muhammad dan A Muhammad, Psikologi Remaja: Perkembangan Peserta Didik (Jakarta: PT. Bumi Aksara, 2004).
} 
rasa aman selama anak belajar, maka ketika pembelajaran dilakukan secara daring orangtua lah yang harus memberikan rasa aman itu, misal dengan memberikan ruang khusus untuk belajar daring yang dikemas semenarik mungkin, bersih, dan rapi serta terhindar dari kebisingan.

Ketiga, Kebutuhan akan rasa kasih sayang dan saling memiliki. Apabila kebutuhan fisiologis dan rasa aman telah terpenuhi, maka rasa kasih sayang akan muncul dalam diri seseorang. Ia akan merasa butuh terhadap kasih sayang dari seorang teman, sahabat dekat, dan kekasih. Kebutuhan ini yang mendorong individu untuk melakukan atau mengadakan hubungan afeksi (hubungan emosional) dengan orang lain yang diaktualisasikan berupa kebutuhan akan rasa memiliki dan dimiliki, mencintai dan dicintai, kebutuhan akan rasa diakui dan diikutsertakan sebagai bagian dari suatu kelompok, merasa dirinya penting, rasa setia kawan, kerjasama dan sebagainya. Perlu dikethui bahwa anak usia dasar hakikatnya masih berada pada masa pubertas, dimana ia menjadi sosok yang sangat ingin diperhatikan, diberi perhatian dan disayang.

Kendati demikian anak-anak masih saja melakukan kesalahan. Mereka cenderung tidak ingin disalahkan, bahkan akan kembali marah, kesal dan menangis jika terus menerus disalahkan. Sikap agresi (rasa kesal, kecewa dan frustasi) masih sangat tinggi khususnya pada anak yang berusia 6-8 tahun. Pada usia ini, anak tidak ingin disalahkan, anak cenderung menampilkan perilaku menyerang (membentak, memukul, menggigit dan sebagainya) terhadap orang yang mengganggunya. Beda halnya dengan anak usia 
9-10 tahun yang sudah bisa membedakan benar atau salahnya suatu perbuatan. Sedangkan pada anak usia 12 tahun ke atas, biasanya ia telah memiliki pandangan yang kompleks dan teratur tentang dirinya sendiri.

Kebutuhan rasa kasih sayang pada anak usia dasar dapat dilakukan dengan cara memberikan perhatian penuh kepada mereka. Misalnya dengan menyediakan sarapan atau bekal makanan, menemani anak ketika belajar, mengajak mereka berwisata (refreshing), bermain, bersanda gurau, membelikan mereka makanan, mainan atau benda-benda yang mereka sukai. Selain itu, di lingkungan sekolah, anak-anak sangat merasa senang dan berperilaku lebih positif ketika segala bentuk perbuatan dan usaha mereka diapresiasi. Contohnya seperti anak-anak yang diberi reward (hadiah) ketika mereka berhasil melakukan suatu hal.

Sebaliknya, anak akan berperilaku negatif dan hilang kepercayaan diri apabila merasa diremehkan, dikucilkan dan merasa terisolasi dari orang-orang disekitarnya. Selama pembelajaran daring, seorang guru dapat melakukan berapa upaya untuk menumbuhkan rasa berharga dalam diri anak, seperti menghargai pendapat anak, memuji hasil karyanya, menegur dengan bahasa yang halus ketika mengingatkan seorang anak yang berbuat salah, melengkapi kekurangannya dan memberi motivasi secara terus menerus. Oleh sebab itu, orangtua harus maksimal memberikan kasih sayang orangtua selama pembelajaran selama pandemi demi tercapainya tujuan pembelajaran.

Keempat, kebutuhan akan rasa harga diri. Kebutuhan akan rasa harga diri merupakan suatu kebutuhan seseorang untuk dapat 
menumbuhkan rasa percaya diri, dimana ia merasa memiliki kapasitas, kredibilitas dan merasa berharga. Maslow membagi kebutuhan akan rasa penghargaan menjadi dua jenis, yaitu: pertama, kebutuhan akan self-respect atau penghormatan/ penghargaan dari diri sendiri, seperti percaya diri, hasrat untuk memiliki kompetensi, kekuatan pribadi, edukasi dan kemandirian. Kedua, yaitu esteem kebutuhan akan penghargaan dari orang lain atas apa yang telah dilakukan, berupa pengakuan, penerimaan, perhatian, kedudukan atau status, pangkat, nama baik dan sebagainya.

Setiap individu pada hakikatnya membutuhkan pengakuan orang lain terhadap kemampuan dan nilai-nilai yang dimilikinya, begitu pula anak usia dasar. Anak usia dasar sangat suka diberi pujian atas segala sesuatu yang mereka kerjakan. Anak akan merasa senang dan bangga ketika mendapatkan suatu penghargaan seperti pujian, hadiah dan dipandang hebat oleh orang lain (orang tua, guru, teman dan sebagainya). Anak juga sangat suka diakui keberadaannya di tengah-tengah orang banyak. Seorang anak yang memiliki cukup harga diri akan merasa lebih percaya diri, aktif, progresif dan lebih produktif. Misalnya, ketika di kelas, jika salah satu anak diberi apresiasi dan disanjung dengan kata-kata seperti hebat, pintar dan rajin di depan teman-temannya, maka ia akan semakin percaya diri dan bangga dengan dirinya. Sebaliknya, anak usia dasar sangat sensitif, mereka akan kesal dan mentalnya akan menurun ketika hasil usaha atau pekerjaan mereka tidak dihargai terlebih dinilai buruk. Rasa malu akan terus menerus menyelimuti dirinya, sehingga tidak jarang seorang anak akan merasa minder dari teman-temannya. 
Oleh sebab itu, sebagai orang tua maupun orang dewasa yang dekat dengan anak mesti pandai memberikan penghargaan untuk meumbuhkan rasa percaya diri anak baik ketika pandemi maupun tidak. Sebab, ketika anak usia dasar kehilangan percaya diri, maka akan berdampak terhadap psikologinya, cenderung menutup diri, rasa tidak berdaya, merasa malu, kehilangan semangat atau gairah hidup dan dapat menimbulkan rasa putus asa, merasa tidak bisa apa-apa yang pada akhirnya merusak mental anak.

Kelima, kebutuhan akan aktualisasi diri. Kebutuhan aktualisasi diri adalah kebutuhan untuk memenuhi dorongan hakiki manusia untuk menjadi orang yang sesuai dengan keinginan dan potensi dirinya. Kebutuhan ini memberikan kecenderungan individu untuk berjuang melakukan apa saja dalam meraih sebuah harapan. Aktualisasi diri ini menjadi suatu kebutuhan yang mendorong individu untuk membuktikan dan menunjukan dirinya kepada orang lain. Pada tahap ini, seseorang semaksimal mungkin mengembangkan segala kemampuan, kapasitas dan potensi yang ia miliki.

Kebutuhan aktualisasi diri menjadi suatu kebutuhan yang paling tinggi. Meskipun kebutuhan-kebutuhan dalam tingkatan sebelumnya sudah terpuaskan, jika kebutuhan akan aktualisasi diri gagal diwujudkan, maka hal ini menjadi penyebab pribadi seseorang akan merasa kecewa, tidak tenang, tidak puas, bahkan dapat dikatakan dalam keadaan tidak sehat secara psikologis. Aktualisasi sebagai tujuan final-ideal hanya dapat dicapai oleh sebagian kecil dari populasi, itupun hanya dalam presentase yang kecil.

Ada beberapa faktor penyebab mengapa kebutuhan aktualisasi diri jarang terpenuhi, yaitu ketika seseorang kesulitan untuk 
menyeimbangkan antara suatu kebanggaan dengan kerendahan hati, antara kemampuan memimpin dengan tanggung jawab yang harus diemban, maupun merasa takut lemah dan merasa tidak mampu. Kebutuhan akualisasi diri pada anak usia dasar masih bersifat ringan dan sederhana. Pada usia tersebut, anak sangat gemar menampilkan kemampuan (skill) yang mereka miliki di depan orang lain. Seringkali anak melakukan suatu tindakan berdasarkan kehendak mereka dan mengekspresikannya secara bebas.

Pada usia 6-9 tahun, anak sangat cepat tertarik dengan sesuatu yang unik dan menyenangkan. Ego mereka masih sangat tinggi sehingga mereka tidak bisa dipaksa untuk melakukan sesuatu yang tidak mereka sukai. Pola pikir mereka juga belum dapat mempertimbangkan sesuatu secara matang, apakah sesuatu itu berdampak baik, berbahaya, merugikan dan sebagainya.

Aktualisasi diri anak usia dasar sangat dipengaruhi oleh faktor eksternal (lingkungan). Pada ranah pendidikan misalnya, anak akan merasa senang dan puas apabila pekerjaan yang dilakukannya berhasil dan berbuah prestasi. Sebaliknya, ia akan merasa kecewa apabila tidak berhasil melakukan pekerjannya tersebut. Hal ini menjadi bukti bahwa rasa sukses merupakan salah satu kebutuhan pokok peserta didik. Sehingga, seyogyanya orang tua dan guru harus mampu mendidik dan mendorong anak untuk mencapai keberhasilan dan prestasi yang tinggi, sesuai dengan apa yang mereka cita-citakan baik ketika pembelajaran dilakukan secara luring maupun daring. Orang tua dan guru juga harus memberikan penghargaan setinggitingginya terhadap pencapaian prestasi anak, walau hanya bernilai standar atau bahkan disaat anak memperoleh kegagalan. Sebagai 
orang tua atau guru harus menghindari perkataan yang kasar dan bernada negatif atau menampakkan sikap tidak puas terhadap anak yang gagal. Pasalnya ini akan berakibat pada kehilangan percaya diri anak, bahkan ia merasa tidak berharga dan putus asa.

\section{KESIMPULAN}

Berdasarkan dari paparan di atas dapat disimpulkan bahwa aspek-aspek kebutuhan anak usia dasar secara umum tidak jauh berbeda dengan orang dewasa, hanya saja yang membedakannya, yaitu pada tingkat kebutuhan atau levelnya. Kebutuhan-kebutuhan anak usia dasar yang harus terpenuhi tentu lebih banyak memerlukan bantuan dari orang lain (Orang tua, kakak, adik, nenek, kakek, guru, teman dan lainnya). Mengingat pada usia dasar, mereka memiliki keterbatasan fisik, pola pikir (abstrak dan operasional konkrit) dan kemampuan motorik yang terbatas. Anak usia dasar juga memiliki sifat yang egois, keras kepala, manja dan sesnsitif yang masih sangat tinggi. Oleh sebab itu, sebagai pihak eksternal, khususnya orang tua dan guru, perlu mengenal, mengetahui, dan memahami jenis dan tingkat kebutuhan peserta didik yang dalam hal ini anak usia dasar.

Pemahaman tentang kebutuhan anak usia dasar dalam pembelajaran terlebih ketika pembelajaran daring selama pandemi Covid-19 sangatlah penting. Orang tua maupun guru haruslah memberikan pembelajaran yang sesuai dengan taraf kebutuhan peserta didik agar tujuan pembelajaran bisa tercapai dengan baik dan maksimal.

\section{DAFTAR PUSTAKA}

Alwisol. Psikologi Kepribadian. Malang: UMM Press, 2009. 
Desmita. Psikologi Perkembangan Peserta Didik. Bandung: Remaja Rosda Karya, 2017.

Mif, B. Psikologi Pertumbuhan. Bandung: Rosdakarya, 2008.

Mualimin, Mualimin. "Konsep Fitrah Manusia dan Implikasinya Dalam Pendidikan Islam." Al-Tadzkiyyah: Jurnal Pendidikan Islam 8, no. 2 (17 November 2017): 249-66. https://doi.org/10.24042/atjpi.v8i2.2130.

Muhammad, A, dan A Muhammad. Psikologi Remaja: Perkembangan Peserta Didik. Jakarta: PT. Bumi Aksara, t.t.

Robert C, Bogdan, dan Biklen Sari K. Qualitative Research for Edducation: an introduction to Theory and Methods. Boston: Ailyn and Bacon, t.t.

Tekeng, St Nurjannah Yunus, dan Asmadi Alsa. "Peranan Kepuasan Kebutuhan Dasar Psikologis dan Orientasi Tujuan Mastery Approach terhadap Belajar Berdasar Regulasi Diri." Jurnal Psikologi 43, no. 2 (1 Juni 2016): 85-106. 
Imam Hanafi | MAHAROT Vol. 5, No. 2, 2021 